\title{
Hvilke oppgaver kan sykepleiere ha i primærhelseteam?
}

Regjeringen har forslått at det skal etableres primærhelseteam i kommunene, med helse- og sosialpersonell som arbeider sammen. Sykepleierne i disse teamene skal overta noen av fastlegenes oppgaver Kanskje kan veiledning av pasienter som trenger å endre usunne vaner være en relevant oppgave?

\section{Forfattere}

\section{Anne Evju}

Helsesykepleier og førstelektor

Bachelor i sykepleie - Institutt for helse- og omsorgsfag Narvik, UiT Norges Arktiske universitet

Ida Skogmo

Sykepleier

Nordlandsklinikken, Russeksjon - Narvik,

Forebygging Kommunehelsetjeneste Livsstil Organisering

Sykepleien 2019 107(75041)(e-75041)

DOI: https://doi.org/10.4220/Sykepleiens.2019.75041

\section{Hovedbudskap}

Regjeringen foreslo i Stortingsmelding nr. 26 at det skal etableres primærhelseteam i kommunene. Første april 2018 startet åtte kommuner et pilotprosjekt. Sykepleiere skal kunne overta oppgaver som fastleger gjør og gi en bedre oppfølging av pasienter som ikke får den oppfølgingen de har behov for i dag. Det er imidlertid fortsatt noe uklart hvilke oppgaver sykepleierne skal overta. Artikkelen diskuterer livsstilveiledning som en mulig oppgave som sykepleiere kan ivareta gjennom primærhelseteam. 
Verdens helseorganisasjon anslår at innen år 2020 vil 70 prosent av all sykdom være livsstilsrelatert.

Sykepleiere kan spille en nøkkelrolle i møte med disse utfordringene, men vi trenger nye arenaer for å nå ut og drive helsefremmende arbeid.

Regjeringen foreslo i Stortingsmelding nr. 26, primærhelsemeldingen (1), at det skal etableres primærhelseteam i kommunene. Et primærhelseteam er definert som en flerfaglig gruppe med helse- og sosialpersonell som arbeider sammen for å levere lokalt tilgjengelige helse- og omsorgstjenester til en definert størrelse uavhengig av alder, kjønn og diagnoser.

Teamet skal i hovedsak bestå av en allmennlege, sykepleier, en administrativt ansatt og ledes av allmennlege (1). Første april 2018, startet åtte kommuner i Norge et pilotprosjekt med primærhelseteam.

Formålet med prosjektet er blant annet: bedret helsetilstand og mestringsevne for pasienter/brukere ved oppfølging av primærhelseteam, økt pasient- og brukertilfredshet, og redusert forekomst og utvikling av behov for omfattende helse- og omsorgstjenester (1). Et helseteam kan være nyttig for eksempel for en pasient med høyt kolesterol og overvekt, der det er viktig å få hjelp i et tidlig forløp for å unngå å utvikle livsstilssykdommer og behov for mer omfattende helsehjelp.

\section{三 «Ideen er at sykepleieren skal kunne overta oppgaver som fastlegen gjør, og gi en bedre oppfølging av pasienter.»}

Ideen er at sykepleieren skal kunne overta oppgaver som fastlegen gjør, og gi en bedre oppfølging av pasienter som ikke får den oppfølgingen de har behov for i dag. Det er imidlertid fortsatt noe uklart hvilke oppgaver sykepleierne skal overta. 
Artikkelen diskuterer livsstilsveiledning som en mulig oppgave som sykepleiere kan ivareta gjennom primærhelseteam. Pasienter som har behov for livsstilsveiledning etterlyser tid hos fastlegen og bedre oppfølgning av primærhelsetjenesten (2). Pasientene har behov for en arena som innretter seg etter prinsippet om tidlig innsats og lavterskel, hvor helsepersonellet har tid og kunnskap til å skreddersy en oppfølging sammen med pasientene. I dag er det fastlegen som er første instans for disse pasientene.

\section{Et vanskelig tema}

Livsstil kan defineres som atferdsmønstre valgt blant de alternativer som er tilgjengelige for menneskene ut fra deres sosioøkonomiske forutsetninger og deres evne til å velge ett alternativ fremfor et annet (3).

Livsstil blir påvirket av både indre og ytre forhold og påvirkes av konteksten mennesket lever i. Faktorer som sosial klasse, utdanningsnivå, geografi, etnisk bakgrunn, kjønn og alder er eksempler på dette. Atferd som røyking, alkoholforbruk, spisevaner og fysisk aktivitet er ofte av privat karakter. Det er et vanskelig tema både for helsepersonell og pasienten det gjelder. Mange pasienter føler at endring av livsstil er noe de bør mestre på egen hånd. De kvier seg for å oppsøke helsevesenet for å få hjelp (4). Samtaler med helsepersonell om livsstil kan oppleves vanskelig (5).

Mange har sågar dårlige opplevelser fra helsevesenet. For eksempel rapporterer personer med overvektsproblematikk at helsepersonell møter dem med dømmende holdninger og avvisning $(6,7)$. Siden temaet kan være av såpass privat karakter vil det være viktig med kontinuitet i oppfølgingen.

\section{«En studie viser at pasienter forventer samtale om overvekt, men at fastlegene ofte unnviker å ta opp dette temaet.»}


For helsepersonell er det også utfordrende å ta opp temaet. En studie viser at pasienter forventer samtale om overvekt, men at fastlegene ofte unnviker å ta opp dette temaet (8). Det kan også være lettere å stille de vanskelige spørsmålene når man har en relasjon til pasienten. Tillit i denne sammenhengen handler derfor om kontinuitet i oppfølgingen, i tillegg til tid og tilgjengelighet (4).

$\AA ̊$ vise empati, respekt, være lyttende og medfølende, er kvaliteter som gjør at pasienter føler mindre skam for å dele privat informasjon, og slike holdninger tar bort frykten for å bli dømt (2). En studie fra en sykepleieledet livsstilsklinikk i Sverige, viste at å føle seg møtt som et likeverdig menneske var avgjørende for hvordan pasientene klarte å ta tak i utfordringene sine (9). Helsepersonellets væremåte og forståelse har vist seg ofte som avgjørende for hvorvidt pasientene er motiverte til livsstilsendring. Det første møtet, som i dette tilfellet er primærlegen, er avgjørende for om pasienten blir motivert til å legge om livsstilen (7).

\section{Hvilke behov har pasientene?}

I veiledning av pasienter som skal endre livsstil er det særlig tre faktorer som bør vies ekstra oppmerksomhet; pasientens motivasjon, mestringstillit og kunnskap om hvordan man går frem for å få til en varig livsstilsendring.

En sentral oppgave for sykepleieren vil være å kartlegge og bidra til å øke pasienters motivasjon gjennom pedagogiske veiledningsteknikker som for eksempel motiverende intervju (MI), som er en evidensbasert samtaleform velegnet i veiledning av pasienter som skal endre livsstil (10). I tillegg til tilstrekkelig motivasjon, må pasienten ha tro på å kunne lykkes. For eksempel må en pasient med diabetes som skal gå ned i vekt, tro på at han vil mestre de endringer som skal til for å klare det. 
Motiverende intervju (MI), også kalt

motiverende samtale, er en effektiv og

empatisk metode for samtaler om endring,

motivasjon og mestring. Målet er

konstruktive samtaler hvor personen får

mulighet til «å overtale seg selv» til å

bestemme at endring skal skje, og så tenke ut

hvordan han best kan få det til.

Kilde: Helsedirektoratet.no

En slik forventningen om å kunne gjennomføre en spesifikk atferd, kalles mestringstillit eller mestringstro (self-efficacy) (11). Hvis pasienten har liten tro på å klare å gjennomføre endringen, er sjansene store for at vedkommende heller ikke vil prøve. Gjennom samtaleteknikker som motiverende intervju ( (12) kan helsepersonellet hjelpe pasienten med å utforske motivasjon for endring og støtte han eller henne i troen på mestring.

Vilje og motivasjon til å gjøre valg som er helsefremmende er imidlertid ikke tilstrekkelig. Når pasienter for eksempel ikke slutter å røyke er det sjeldent fordi de ikke vet at det er helseskadelig å røyke. Det kan handle om at de ikke vet hvordan de skal gå frem for å endre på denne helseatferden eller en generell følelse av avmakt i forhold til egen helse (13).

Det er store variasjoner i pasienters evner til å bruke helseinformasjon. Noen pasienter forholder seg i liten grad til helseinformasjon, mens andre gjør systematisk og kritisk gjennomgang av helseinformasjon, og benytter det de lærer til å ta ansvar for sin egen helse (14). Denne typen ferdigheter som individet trenger for å skaffe seg tilgang til og forstå og bruke informasjon til å fremme sin helse, kalles for helsefremmende allmenndannelse (health literacy) (15). 
Studier viser at pasienter med lav helsefremmende allmenndannelse ofte får dårligere behandling i helsevesenet og er oftere gjengangere i helsevesenet. Dette kan ha sammenheng med manglende evne til å uttrykke seg faglig om sitt problem (16-18) og manglende forståelse for hva legen formidler (19). Disse pasientene får problemer med å følge råd og behandlingsregimer, og har gjerne utfordringer i forhold til å navigere i helsetjenestesystemet (17).

For å tilrettelegge for en helsefremmende dialog tilpasset den enkeltes behov, må helseinformasjon derfor være individuelt skreddersydd (13). Dette krever at helsepersonellet har god kjennskap til pasientens helsefremmende allmenndannelse. Studier viser ingen forskjell på hvem som følger opp disse pasientene (sykepleier, lege eller psykolog), men helsepersonellet må ha tid til en grundig gjennomgang med pasienten slik at de forstår hverandre (13). Intervensjonen må pågå over en viss tid og være bygd på en god relasjon preget av partnerskap og tillit.

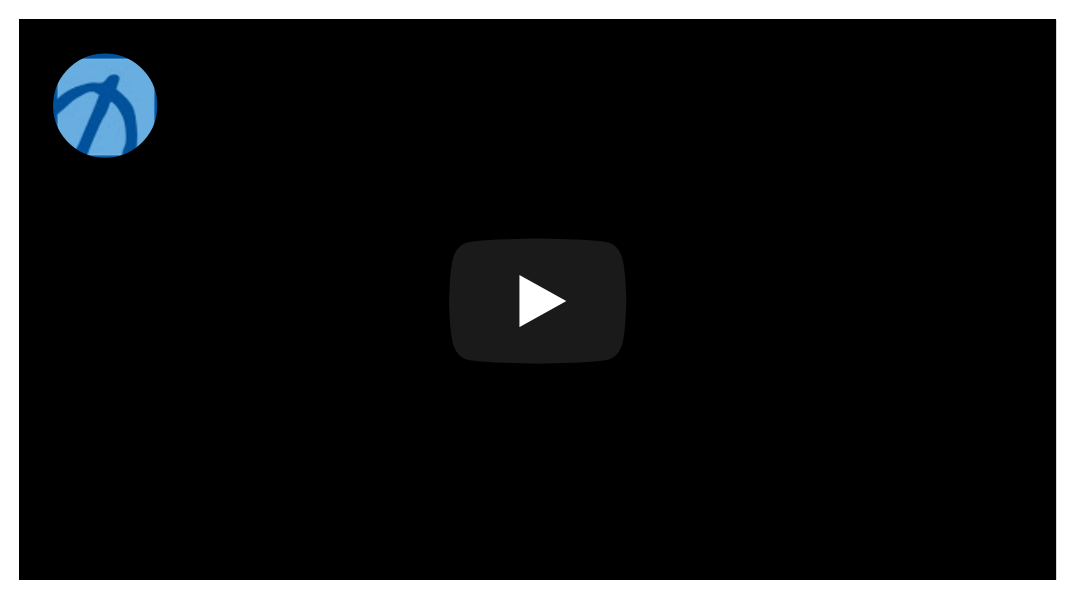

MOTIVERENDE INTERVJU: Filmen viser hvordan endringssnakk kan gjøres. Kilde: KoRus-Øst

\section{Bedre tilbud?}

Fastlegen er ofte den første som møter pasientene som står i fare for å utvikle livsstilssykdommer. Legene har lite tid til livsstilsveiledning innenfor sine korte konsultasjoner. Slik situasjonen er i dag får de utsatte pasientene mangelfull oppfølging (2). 
Forskning har vist at overvektige pasienter med livsstilsutfordringer, opplevde at fastlegen viste utilstrekkelig engasjement og overlot ansvaret for informasjon om tilgjengelige behandlinger og tilbud til pasientene selv. De opplevde konsultasjonene som forhastede og preget av medisinsk informasjon de ikke kunne forstå og mange var tilbakeholdne med å dele informasjon av privat karakter (8).

Det er imidlertid viktig å påpeke at mange leger gjør en svært viktig jobb i veiledning av disse pasientene. De har gjerne kjent pasienten i mange år og har god innsikt i det totale bildet til pasienten. Tidsrammene er imidlertid ikke tilpasset pasientenes behov. Fastlegene rapporterer om en arbeidstid på i gjennomsnitt 46 timer i uken og deres kapasitet er strukket (1).

Sammenliknet med andre OECD-land har Norge en høy allmennlegedekning, men legekontorene har færre med annen helsefaglig utdanning. Slik systemet fungerer i dag ser vi at fastlegene har begrensede muligheter til å drive primærforebyggende- og helsefremmende veiledning, selv om de som førstehåndstjeneste har en unik mulighet til å fange opp risikopasientene. Med bakgrunn i dette er det relevant å se på alternative måter å organisere veiledning og oppfølgingen til disse pasientene. Kan en løsning være at sykepleierne overtar oppfølgingen av disse pasientene i fastlegekontorene gjennom primærhelseteam?

\section{Sykepleiere på legekontorene}

Sykepleiere er godt kvalifiserte til å følge opp pasienter med livsstilsutfordringer. I spesialisthelsetjenestens poliklinikk kan pasientene få behandling av sykepleier, uten å møte lege. Vi ser ingen grunn til at dette ikke er mulig å overføre til primærhelsetjenesten. Pasientene vil møte kompetente sykepleiere som både kan ivareta den veiledende og rådgivende funksjonen som disse pasientene har behov for. 
Land som USA, England og Nederland har en slik arbeidsfordeling. I Nederland har man for eksempel introdusert en slags allmennpraktiserende sykepleier som blant annet veileder i forhold til levevaner.

Studier viser til gode erfaringer med en slik arbeidsfordeling. De gjør vitale målinger og følger opp veiledning og rådgiving (20). En nederlandsk studie viser at pasientene var tilfredse med hvordan disse sykepleierne koordinerte omsorgen (21). I studien rapporterte pasientene som hadde konsultasjoner med sykepleiere om tettere oppfølging og lengre konsultasjoner enn ved legekonsultasjoner. Studien viste også at sykepleierne ga mer informasjon, råd og konkret veiledning enn legene gjorde og tok generelt bedre vare på pasientenes egenomsorg.

\section{三 «Pasienter som skal endre livsstil har gjerne komplekse problemstillinger.»}

Flere studier viser god effekt av sykepleieledet oppfølging av pasienter som skal endre livsstil, på bakgrunn av sykepleiernes brede kompetansefelt (4, 22, 23). Pasienter som skal endre livsstil har gjerne komplekse problemstillinger, og ofte helsemessige utfordringer i tillegg til at de trenger å endre levevaner.

En svensk studie som omhandler oppfølging av pasienter på en kommunal livsstilsklinikk, viser at pasienter med livsstilsutfordringer føler seg godt ivaretatt av sykepleiere på grunn av den helhetlige kunnskapen de besitter. I tillegg til å bli møtt som likeverdige mennesker, kunne pasientene få råd og veiledning på alt fra medikamenter, fysisk aktivitet, kosthold og følelsesmessige utfordringer (9).

\section{$\varnothing k t$ helsegevinst}


Slik vi forstår det så foreligger ingen fastsatte rammer på hvordan et primærhelseteam skal fungere og hvilke oppgaver sykepleieren skal ta over. Tanken bak å sette i gang med teamet skal være å gi befolkningen et så tilgjengelig, enkelt og proaktivt tilbud som mulig. Vi ser for oss at pasienter som kommer til fastlegen og får avdekket utfordringer vedrørende livsstil kan følges videre opp hos sykepleier. Oppfølgingen og veiledningen kan omhandle kosthold, fysisk aktivitet, drikke- og røykevaner samt samtaler rundt stressrelaterte problemstillinger.

Gjennom veiledende samtaleteknikker som støtter motivasjon og mestringstro, og gjennom å skreddersy informasjon og råd, vil pasienten kunne få en oppfølging som er mer rettet mot livsstilsendring. Den medisinske behandlingen ivaretas av fastlegen, mens måling av vitale parametere og veiledning kan sykepleieren utføre. Slik sett likner behandlingen en organisering som poliklinikker og kommunale diabetessykepleiere har i dag.

En slik organisering vil imidlertid ikke løse verken lege- eller sykepleiemangel. Det bør da heller ikke være intensjonen, men sammenliknet med leger, er det flere sykepleiere i primærhelsetjenesten. Sykepleierne har grunnleggende kompetanse knyttet til helse, kosthold, vekt og fysisk aktivitet. Sykepleiere har gode forutsetninger for å ivareta veiledningen av disse pasientene og slik sett vil det være rett profesjon på rett sted. Det vil kunne gi en bedre utnyttelse av helsekronene og være besparende for samfunnet.

Det viktigste med en slik organisering av primærhelsetjenesten er likevel at primærhelseteam kan bidra til bedre samhandling i de kommunale tjenestene rundt pasienter som har behov for å endre livsstil, og dermed øke helsegevinsten for pasientene.

\section{Referanser}


1. $\quad$ Meld. St. nr. 26 (2014-2015). Fremtidens primærhelsetjeneste - nærhet og helhet. Oslo: Helseog omsorgsdepartementet; 2015.

2. Rocque R, Leanza Y. A systematic review of patients' experiences in communicating with primary care physicians: intercultural encounters and a balance between vulnerability and integrity. PLoS One 2015;10(10):e0139577.

3. Milio N. Promoting health through public policy. Ottawa: Canadian Public Health Assoc; 1986.

4. Evju AS, Klette GS, Kasén A, Bondas T. «Vi går inn i det private rommet til pasienten»; sykepleieres erfaring med helsefremmende arbeid i somatiske polikliniske. Nordisk tidsskrift for helseforskning. 2014;10(1):70-82.

5. $\quad$ Prescott P, Børtveit T. Helse og atferdsendring. Oslo: Gyldendal Akademisk; 2004.

6. Thomas SL, Hyde J, Karunaratne A, Herbert D, Komesaroff PA. Being 'fat' in today's world: a qualitative study of the lived experiences of people with obesity in Australia. Health Expectations. 2008;11(4):321-30.

7. Borge L, Christiansen B, Fagermoen MS. Motivasjon til livsstilsendring hos personer med sykelig overvekt. Sykepleien forskning. 2012;1(7):1422.

8. Malterud K, Ulriksen K. Obesity in general practice. Scand J Prim Health Care. 2010;28(4):20510.

9. Nymberg P, Drevenhorn E. Patients' experience of a nurse-led lifestyle clinic at a Swedish health centre. Scand J Caring Sci. 2016;30(2):349-55 
10. McKenzie KJ, Pierce D, Gunn JM. A systematic review of motivational interviewing in healthcare: the potential of motivational interviewing to address the lifestyle factors relevant to multimorbidity. J Comorb. 2015;5(1):162-74.

11. Bandura A. Self-efficacy: the exercise of control. New York: Freeman; 1997.

12. Miller W, Rollnick S. Meeting in the middle: motivational interviewing and self-determination theory. Int J Behav Nutr Phys Act. 2012;(9):25.

13. Wangberg SC, Evju AS, Høgbakk ML. Helsefremmende allmenndannelse («Health literacy») - en viktig ressurs. I: Kassah BL, Tingvoll W-A, Nordahl-Pedersen H, red. Forebyggende helsearbeid: sykepleie i kommunal helse- og omsorgstjeneste. Oslo: Gyldendal Akademisk; 2016.

14. Beacom AM, Newman SJ. Communicating health information to disadvantaged populations. Fam Community Health. 2010;33(2):152-62.

15. Nutbeam D. Health promotion glossary. Health Promot Int. 1998;13(4):349-64.

16. Ishikawa H. YE. Patient health literacy and participation in the health-care process. Health Expect. 2008;11(2):113-22.

17. Berkman ND, Sheridan SL, Donahue KE, Halpern DJ, Crotty K. Low health literacy and health outcomes: an updated systematic review. Ann Intern Med. 2011;155(2):97-107.

18. Berkman ND, Sheridan SL, Donahue KE, Halpern DJ, Viera A, Crotty K, et al. Health literacy interventions and outcomes: an updated systematic review. Evid Rep Technol Assess (Full Rep). 2011; (199):1-941. 
19. Schillinger D, Bindman A, Wang F, Stewart A, Piette J. Functional health literacy and the quality of physician-patient communication among diabetes patients. Patient Educ Couns. 2004;52(3):315-23.

20. Jansink RME, Braspenning JCC, Weijden GDEMvd, Elwyn G, Grol RPTM. Primary care nurses struggle with lifestyle counseling in diabetes care: a qualitative analysis. BMC Fam Pract. 2010;11:41.

21. Dierick-Van Daele ATM, Metsemakers JFM, Derckx EWCC, Spreeuwenberg C, Vrijhoef HJM. Nurse practitioners substituting for general practitioners: randomized controlled trial. J Adv Nurs. 2009;65(2):391-401.

22. Carrington MJ, Zimmet P. Nurse health and lifestyle modification versus standard care in 40 to 70 year-old regional adults: study protocol of the Management to Optimise Diabetes and mEtabolic syndrome Risk reduction via Nurse-led intervention (MODERN) randomized controlled trial. BMC Health Serv Res. 2017;17(1):813.

23. Voogdt-Pruis HR, Beusmans GHMI, Gorgels APM, van Ree JW. Experiences of doctors and nurses implementing nurse-delivered cardiovascular prevention in primary care: a qualitative study. J Adv Nurs. 2011;67(8):1758. 